\title{
INDIRECT in vitro ORGANOGENESIS OF Hancornia speciosa GOMES
}

\author{
ORGANOGÊNESE INDIRETA in vitro DE Hancornia speciosa GOMES
}

\author{
Débora de Oliveira PRUDENTE ${ }^{1}$; Renato PAIVA² Fernanda Carlota NERY $^{2}$; \\ Wesley Pires Flausino MÁXIMO ${ }^{1}$; Luciano Coutinho SILVA ${ }^{3}$ \\ 1. PhD. Student, Universidade Federal de Lavras-UFLA, Lavras, MG, Brazil. deboraoprudente@ outlook.com; \\ 2. Professor (a), PhD., Universidade Federal de Lavras-UFLA, Lavras, MG, Brazil; 3. Professor, PhD., Universidade Federal da \\ Paraíba-UFPB, Brazil, João Pessoa, PB, Brazil.
}

\begin{abstract}
Hancornia speciosa Gomes is a fruit species belonging to the Apocynaceae family and holds social, cultural and economic potential mostly due to its use in composition of many food industry products and the consumption its fruits in natura. Several aspects regarding their propagation need further studies, since the species is undergoing a continuous process of domestication. The objective was to obtain an in vitro protocol for indirect organogenesis and rooting with subsequent acclimatization of $H$. speciosa plants. To obtain indirect organogenesis, internodal segments were inoculated in WPM culture medium gelled with $7 \mathrm{~g} \mathrm{~L}^{-1}$ agar, added with $30 \mathrm{~g} \mathrm{~L}^{-1}$ sucrose, $0.4 \mathrm{~g} \mathrm{~L}$ ${ }^{-1}$ PVP, and supplied with different concentrations of 2,4-D $(0.0 ; 2.46 ; 7.38 ; 12.30$; and $17.22 \mu \mathrm{M})$, BAP $(0.0 ; 4.92 ; 9.84$; 14.76; and $19.68 \mu \mathrm{M})$, and $\mathrm{TDZ}(0.0 ; 4.92 ; 9.84 ; 14.76$; and $19.68 \mu \mathrm{M})$. For the in vitro rooting, shootings with approximately $6.0 \mathrm{~cm}$ diameter length kept for 15 days in WPM medium with no plant growth regulator and, afterwards, subjected to treatments with different auxins (Control; $9.84 \mu \mathrm{M}$ IBA; $9.84 \mu \mathrm{M}$ NAA; and $9.84 \mu \mathrm{M}$ IAA) as well as the combination among them, in order to verify their effects on percentage of rooting (\%), number of roots, and average length of the largest root $(\mathrm{cm})$. The formation of calluses was observed in all explants subjected to the concentrations of the regulators tested. The highest shooting regeneration occurred with $7.38 \mu \mathrm{M} 2,4-\mathrm{D}(73 \%)$. The highest percentage of shoot rooting $(80 \%)$ and roots with the largest length $(1.3 \mathrm{~cm})$ were found in the culture medium with the combination of 4.92 $\mu \mathrm{M}$ NAA and $4.92 \mu \mathrm{M}$ IBA. The in vitro regeneration of $H$. speciosa is feasible. The acclimatization of rooted shoots in Trospstrato ${ }^{\circledR}$ was accomplished with successful and $100 \%$ survival of plant material was observed during this stage.
\end{abstract}

KEYWORDS: Fruit species. Apocynaceae. Cerrado. Native species.

\section{INTRODUCTION}

The production of fruit stands out in agriculture worldwide mostly due to economic and social importance creating jobs and moving the economy (SANTOS FILHO et al., 2014). Since 2008, Brazil has been among the three largest fruit producers around the world, representing $5 \%$ of the world's production only behind China and India (SANTANA NETA et al., 2013).

Even though Brazil is among the main fruit producers in the world, several native fruit species are poorly commercialized in the country which is result of the few technified plantations intended to large-scale production. In addition, these species are extracted by local communities mostly because of the high nutritive value of their fruits (SILVA JÚNIOR, 2004). These ones, once harvested, are either consumed in natura or processed in industries (SOARES et al., 2011), which affects the dispersal of seeds and the reproduction of the species.

Among the several species with commercial exploitation potential, Hancornia speciosa Gomes popularly known as 'mangabeira' is noteworthy. It has a wide geographic distribution covering the territory from the State of Amapá to the State of São Paulo (MACHADO et al., 2004). It holds great economical potential because there are several possibilities to use their fruits to produce syrups, juices, pastries, ice cream, and jams (SOARES et al., 2011). Additionally, the latex exuded by the plant may be used in popular medicine to fight tuberculosis (SOUSA et al., 2005), inflammation, ulcers and herpes (MOURA; AGRA, 1989; SILVA JÚNIOR, 2004).

Although the species presents many advantages that allow it to be used towards trade, the water content below $25 \%$ in their seeds may impair its germination in field, reducing the productivity of the species and decreasing the availability of products from 'mangabeira' (BARROS et al., 2006). The main causes of the low germination are related to the seeds recalcitrance which also hardens long-term storage, besides the presence of certain inhibitors able to perform the fermentation and produce phenolic compounds in fruit pulp (OLIVEIRA; VALIO, 1992; LORENZI, 2000; BARROS et al., 2006; SANTOS et al., 2010).

Asexual propagation techniques have represented an important tool to overcome natural obstacles underlying vegetal species enabling the commercial cultivation in a shorter time and producing disease-free plants (MACHADO et al., 2004). The micropropagation is one of these asexual 
propagation techniques which allow the multiplication of species with desirable characteristics in a short-term and suitable phytosanitary conditions (ULISSES et al., 2010).

Within micropropagation, one of the most used morphogenic pathways is the indirect organogenesis where the early explant undergoes callus stage before forming new plants in vitro. It can provide promising results when it is aimed to increase the number of seedlings at the end of the micropropagation and solve natural recalcitrance problems. Thus, studies involving callus induction processes and shooting regeneration may help on the optimization of tissue culture protocols enabling studies on the subsequent stages of micropropagation which allow the large-scale multiplication of the species (PEREIRA et al., 2013).

Considering the scarcity of works related to the organogenesis of $H$. speciosa, the present work aimed the establishment of a micropropagation protocol via indirect organogenesis in order to provide regenerated shoots to the rooting and acclimatization stages.

\section{MATERIAL AND METHODS}

The study was conducted at the Plant Tissue Culture Laboratory in the PLant Physiology Section, Department of Biology, Federal University of Lavras (UFLA) in Lavras, Minas Gerais State, Brazil.

H. speciosa shootings previously multiplied in vitro in Wood Plant Medium (WPM) (LLOYD; MCCOWN, 1980) supplied with $8.87 \mu \mathrm{M}$ 6benzylaminopurine (BAP), $0.09 \mathrm{M}$ sucrose and gelled with 7 g.L. ${ }^{-1}$ agar as established by Soares et al. (2011) were used as explant source.

Internodal segments with an average size of $1,0 \mathrm{~cm}$ from plants obtained in vitro were inoculated in WPM culture medium gelled with $7.0 \mathrm{~g} \mathrm{~L}^{-1}$ agar, added with $30 \mathrm{~g} \mathrm{~L}^{-1}$ sucrose, and $0.4 \mathrm{~g} \mathrm{~L}^{-1}$ de polyvinylpyrrolidone (PVP) supplied with different types and concentrations of growth regulators: (i) 2,4-dichlorophenoxyacetic acid (2,4-D) $(0.00 ; 2.46$; 7.38; 12.30 and $17.22 \mu \mathrm{M})$; (ii) BAP $(0.00 ; 4.92$; 9.84; 14.76 and $19.68 \mu \mathrm{M}$ ) and (iii) Thidiazuron (TDZ) $(0.00 ; 4.92 ; 9.84 ; 14.76$ and $19.68 \mu \mathrm{M})$. Explants were inoculated at laminar flow chamber at $25{ }^{\circ} \mathrm{C} \pm 2{ }^{\circ} \mathrm{C}$ temperature in the dark. After 30 cultivation days, the percentage of callus formation and the regeneration of shootings were measured.
Following 60 days in vitro regeneration, the shoots were individually transferred onto WPM culture medium without plant growth regulators and cultured for 15 days. Afterwards, shoots with approximately $6.0 \mathrm{~cm}$ in length were transferred to culture medium added with $30 \mathrm{~g} \mathrm{~L}^{-1}$ sucrose and supplied with $9,84 \mu \mathrm{M}$ of the following auxins: indole-3-butyric acid (IBA), 1-naphthalaeneacetic acid (NAA) and indole-3-acetic acid (IAA). Furthermore, the combinations between those regulators $(4.92 \mu \mathrm{M}$ IAA + $4.92 \mu \mathrm{M}$ IBA; $4.92 \mu \mathrm{M}$ $\mathrm{NAA}+4.92 \mu \mathrm{M} \mathrm{IBA}$; and $4.92 \mu \mathrm{M} \mathrm{NAA}+4.92$ $\mu \mathrm{M}$ IAA) have also been tested. Explants were incubated throughout 30 days in growth chamber at $25{ }^{\circ} \mathrm{C} \pm 2{ }^{\circ} \mathrm{C}$ temperature, 16-hour photoperiod and $36 \mu \mathrm{mol} \mathrm{m} \mathrm{m}^{-2} \mathrm{~s}^{-1}$ photons irradiance. The evaluated variables were the percentage of rooting (\%), number of roots and average length of the largest $\operatorname{root}(\mathrm{cm})$.

Plants obtained using indirect organogenesis and in vitro rooting went through a 7-day preacclimatization period in $250 \mathrm{~mL}$ tubes with Tropstrato $^{\circledR}$ substrate covered with a transparent plastic bags in order to maintain the moisture. The vegetal material was kept in growth chamber at 25 ${ }^{\circ} \mathrm{C} \pm 2{ }^{\circ} \mathrm{C}$ controlled temperature and $67 \mu \mathrm{mol} \mathrm{m} \mathrm{m}^{-2} \mathrm{~s}^{-}$ ${ }^{1}$ photons irradiance. Afterwards, the recipient was opened and plants stayed more 15 days in an acclimatization room. Tubes with plants were taken to the greenhouse where they were kept for another 15 days before transplanting to pots containing Tropstrato $^{\circledR}$ substrate. After 30 days in the greenhouse, the percentage of plant survival was measured.

All the experiments were performed in a completely randomized design with 30 replications per treatment, which consisted of one tube with one explant. Data were subjected to the analysis of variance (ANOVA) using the statistical software Sisvar $^{\circledR}$ (FERREIRA, 2011) and means compared by Scott-knott test at 5\% probability.

\section{RESULTS AND DISCUSSION}

No differences were observed among the concentrations tested for the growth regulators BAP, TDZ, and 2,4-D with a $100 \%$ callus formation in all treatments assessed. However, it was noteworthy that the highest callus formation occurred in the presence of growth regulators when compared to their absence in the culture medium (Figures 1A, $1 \mathrm{~B}$, and $1 \mathrm{C})$ 

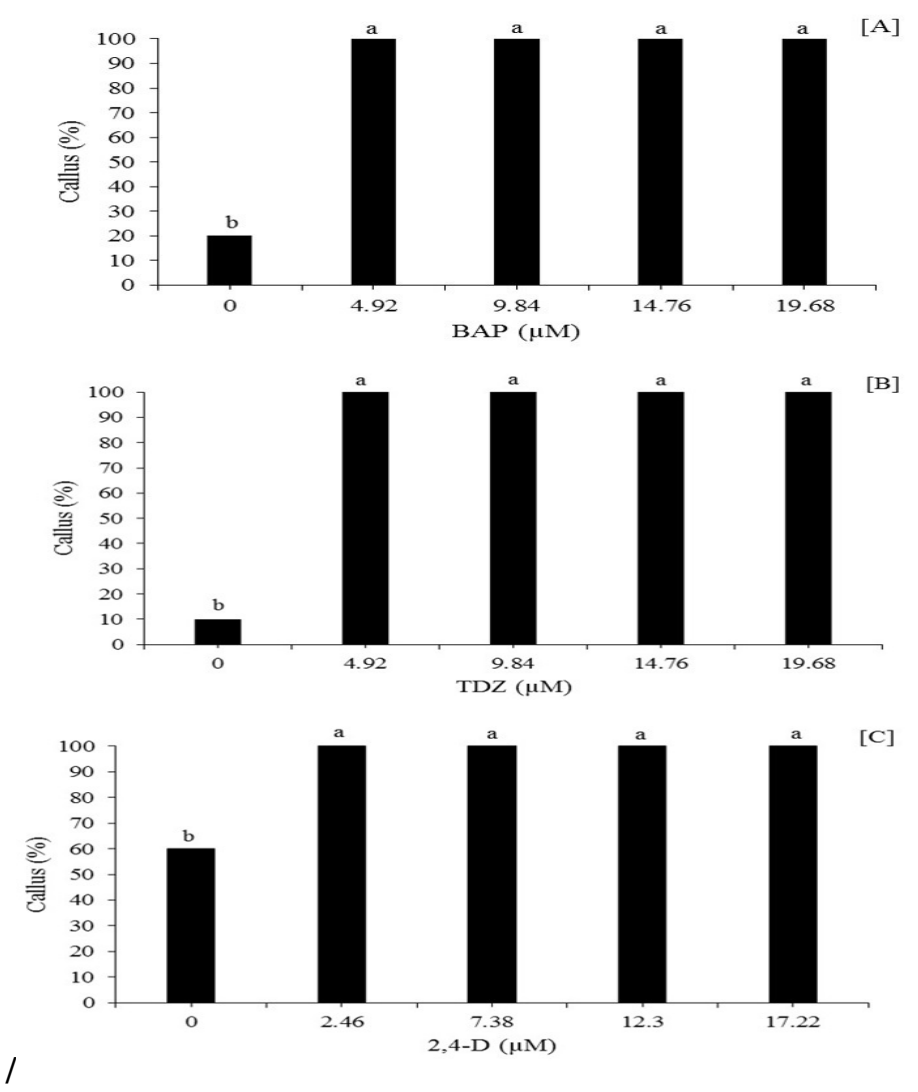

Figure 1. Percentage of callus formation in the internodal stem segments of $H$. speciosa subjected to different concentrations of BAP $(0.0 ; 4.92 ; 9.84 ; 14.76$ and $19.86 \mu \mathrm{M})(\mathrm{A})$, TDZ $(0.0 ; 4.92 ; 9.84 ; 14.76$ and $19.68 \mu \mathrm{M})(\mathrm{B})$, and $2,4-\mathrm{D}(0.0 ; 2.46 ; 7.31 ; 12.30$ and $17.22 \mu \mathrm{M})(\mathrm{C})$ at 30 days of in vitro cultivation in WPM medium. Different letters in bars show statistical differences between them according to Scott-Knott test at 5\% probability.

According to the results, it was found that the different growth regulators as well as their concentrations influenced significantly the dedifferentiation of the internodal segments in

calluses (Figure 1). Explants inoculated in the absence of growth regulators have also influenced callus formation at 30 days of cultivation, yet in a lower frequency and swollen (Figure 2A).

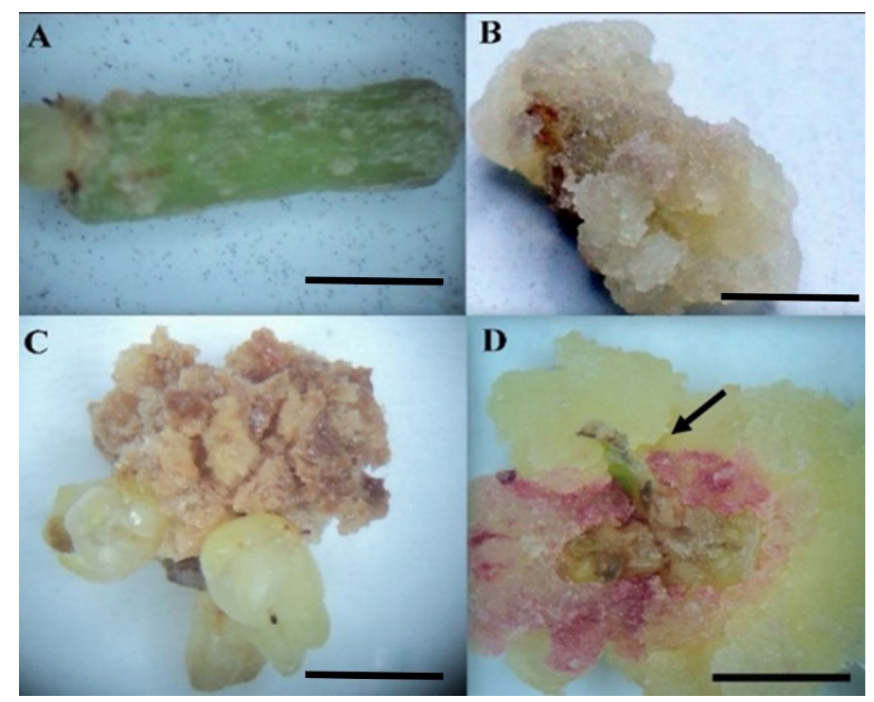

Figure 2. Visual appearance of calluses formed in internodal stem segments of $H$. speciosa in WPM culture medium with no presence of growth regulators (A), supplied with $9.84 \mu \mathrm{BAP}(\mathrm{B}), 9.84 \mu \mathrm{M}$ TDZ (C) and 7,38 $\mu \mathrm{M} 2,4-\mathrm{D}(\mathrm{D})$. The arrow evidences the regeneration of shootings at 30 days of in vitro cultivation in WPM medium containing 7,38 $\mu \mathrm{M} 2,4-\mathrm{D}(\mathrm{D})$. Bar $=0.5 \mathrm{~cm}$ 
Calluses from the cultivation in the presence of BAP and 2,4-D were friable, easy to dissociate and exhibited initial white coloration (Figure 2B and 2D). Callus obtained after the use of TDZ in the culture medium were initially dark-brown colored and exhibited subsequent oxidation of the explant (Figure 2C).

The subsequent differentiation of calluses in shootings was obtained in the concentrations of 9.84 $\mu \mathrm{M}$ BAP and $14.76 \mu \mathrm{M}$ TDZ (Figure $3 \mathrm{~A}$ and $3 \mathrm{~B}$ ) as well as in all 2,4-D concentrations tested (Figure $3 \mathrm{C})$. Among the 2,4-D concentrations, the highest percentage of shootings (73\%) was obtained using $7.38 \mu \mathrm{M}$ this auxin into the medium. No shoot regeneration was observed in any treatment without plant growth regulator.
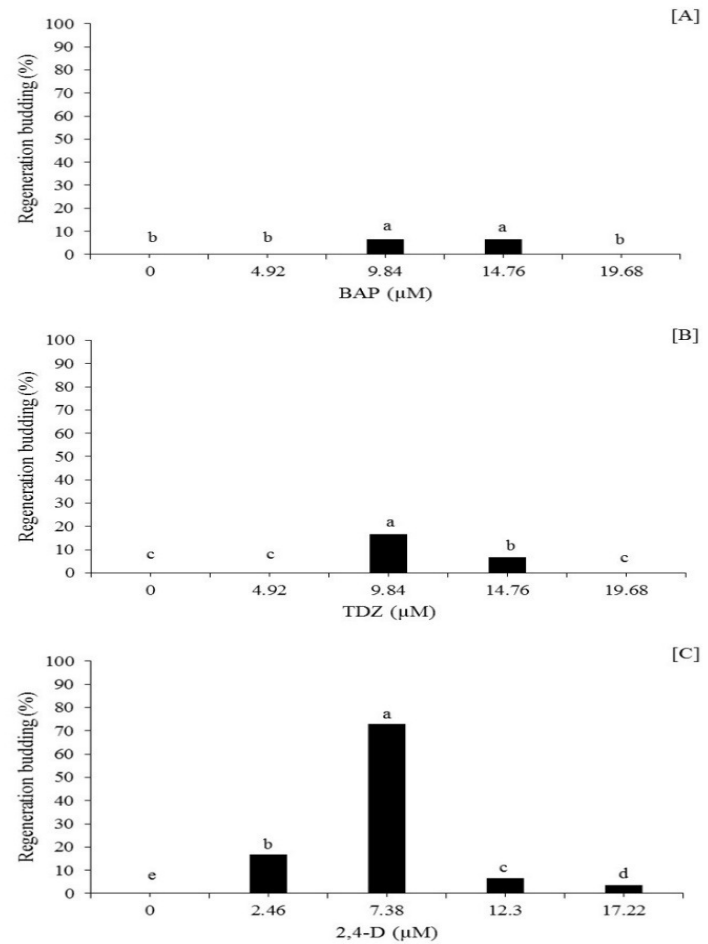

Figure 3. Regeneration of shootings in calluses formed from internodal stem segments of $H$. speciosa subjected to different concentrations of BAP $(0.0 ; 4.92 ; 9.84 ; 14.76$ and $19.68 \mu \mathrm{M})(\mathrm{A})$, TDZ $(0.0$; $4.92 ; 9.84 ; 14.76$ and $19.68 \mu \mathrm{M})(\mathrm{B})$ and $2,4-\mathrm{D}(0.0 ; 2.46 ; 7.31 ; 12.30$ and $17.22 \mu \mathrm{M})(\mathrm{C})$ at 30 days of in vitro cultivation in WPM medium. Different letters in bars show statistical difference between them according to Scott-Knott test at 5\% probability.

A study on young leaves of Melothria maderaspatana (Linn.) has also showed the highest percentage of callus formation $(98 \%)$ with further shooting regeneration in the culture medium supplied with $6.0 \mu \mathrm{M}$ 2,4-D and $0.5 \mu \mathrm{M}$ TDZ (BASKARAN et al., 2009) which demonstrates that the presence of 2,4-D was crucial to obtain the result. The superiority of this synthetic auxin in comparison to other auxin and cytokinin sources during indirect organogenesis has also been recorded in essays with Lavandula angustifolia buds in which the use of $4.52 \mu \mathrm{M} 2,4-\mathrm{D}$ and $1.44 \mu \mathrm{M}$ $\mathrm{GA}_{3}$ in the culture medium was the most suitable combination to induce calluses (BONA et al., 2012), as well as for leaf segments of Myracrodruon urundeuva in which the use of $4.52 \mu \mathrm{M}$ 2,4-D promoted the highest rate of callus formation
(VASCONCELOS et al., 2012). The importance of the auxins as an inductor of the cell competence is known and the 2,4-D has been particularly reported in literature as a necessary regulator for the somatic cell dedifferentiation (RAGHAVAN, 2004; PINTO et al., 2010; LI et al., 2012) most of all from parenchyma cells of vascular bundles (LI et al., 2012).

In the present paper, it was observed that the combination between the endogenous content of internodal segment phytohormones of $H$. speciosa with the addition of $7.38 \mu \mathrm{M} 2,4-\mathrm{D}$ to the culture medium stimulated the cell division from competent parenchyma regions, addressing dedifferentiated cells to form shootings in calluses.

Shootings exhibited higher rooting percentage (80\%), higher number of roots (4.8) and 
larger length of roots $(0.4 \mathrm{~cm})$ when inoculated in culture medium with the combination of $4.92 \mu \mathrm{M}$
NAA and $4.92 \mu \mathrm{M}$ IBA (Figure 4A, 4B, and 4C).
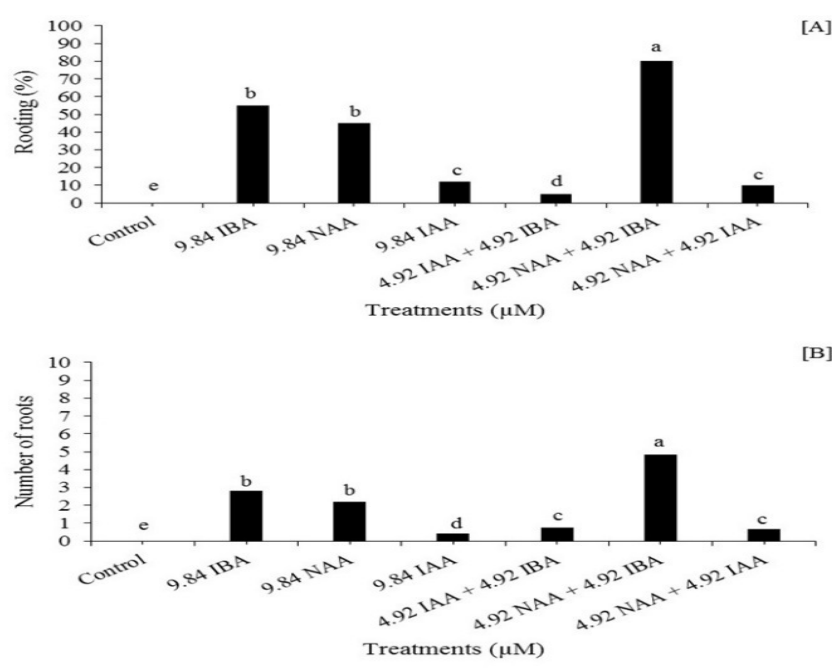

[B]

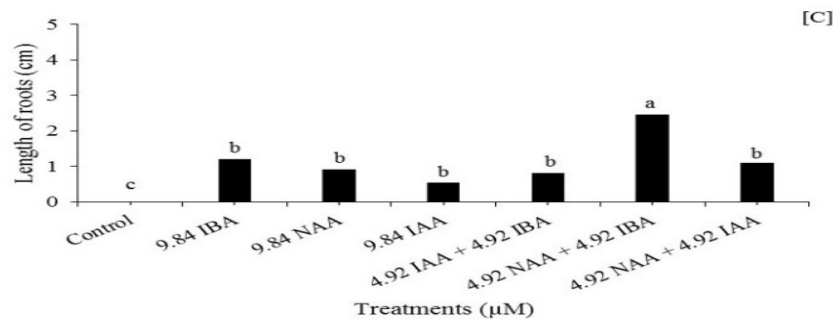

Figure 4. Influence of different types and concentrations of auxins added to WPM medium on the percentage of rooting (A), average number of roots (B) and average length of roots of $H$. speciosa shootings cultivated in vitro for 30 days. Different letters in bars show statistical differences between them according to Scott-Knott test at 5\% probability.

The adventitious rooting process encompasses the conjunction of internal and external auxins and when the species has proper IAA content, endogenous phytohormones, the conjunction with synthetic growth regulators such as IBA or NAA for a given period is sufficient to induce rooting in in vitro conditions (SOUZA et al., 2011). On cherry-tree, a woody species, it was found that 2,46 $\mu \mathrm{M}$ IBA in half-strength WPM culture medium was enough to induce rooting and lower auxin concentrations favored the length of the main root (FERMINO JUNIOR; PEREIRA, 2012). Regarding the species Desmodium gangeticum (L.) DC. (CHERUVATHUR; ABRAHAM; THOMAS, 2013) and Parapiptadenia rigida (Benth.) Brenan (KIELSE et al., 2009), both woody, the concentration of $4.92 \mu \mathrm{M}$ IBA provided the highest rooting frequency.

The formation of adventitious roots is related to the interaction of auxins supplied to the culture medium as well as cofactors synergistically acting in roots. Usually, such factors are synthesized in buds and young leaves with subsequently transport through the phloem from the synthesis site (FACHINELLO et al., 1995). The IBA exogenously supplied is transported to the leaves, stimulates a higher IAA production and, therefore, it is transported to the initial rooting zone (FORD et al., 2001). As $H$. speciosa shootings exhibited lateral buds and young leaves in the initial developmental stage in vitro (Figure $5 \mathrm{~A}$ ), such mechanism might be activated by using IBA and NAA dosages provided altogether to the culture medium stimulating the development and growth of roots.

Roots formed from shootings obtained through indirect organogenesis had morphological changes after cultivation under the influence of the different treatments. Roots induced by auxins isolated in the culture medium were thinner and displayed difficulty to growing in depth (Figure 5A) probably due to the presence of calluses at the base of shootings. On the other hand, roots formed in the presence of the combination of IBA and NAA had a slight rooting thickening and improved growing in depth (Figure 5B). 


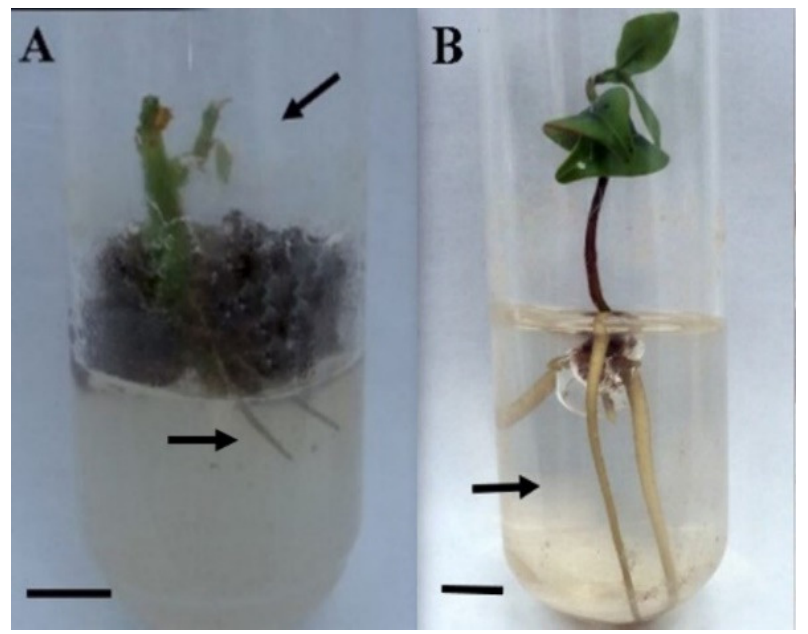

Figure 5. Visual aspect of $H$. speciosa shoots rooted in vitro in WPM culture medium supplied with $9.84 \mu \mathrm{M}$ NAA (A) and the combination of $4.92 \mu \mathrm{M}$ NAA and $4.92 \mu \mathrm{M}$ IBA (B) after 30 days of in vitro culture. The arrows in (A) show the formation of shooting and the induction of roots from the callus at the base of explants, whereas in (B) the arrow shows the induction of roots from the base of explants. Bars $=1.0 \mathrm{~cm}$

In general, woody species have more difficulty regarding adventitious rooting. This stage is even more difficult when the shooting is from indirect organogenesis because the formation of calluses at base of shoots, which may jeopardize the differentiation of roots (MANTOVANI et al., 2010; OLIVEIRA; DIAS; BONDANI, 2013). However, the callus may have either isolated cells or in groups with active centers of cell division, which once properly induced enable the production of new organs (JARDIM et al., 2010), which might explain the rooting of shoots with calluses at the base of explant. However, usually at the acclimatization phase only photosynthesis is playing a role as an energy supplier to the plant from in vitro cultivation. Thus, the in vitro adventitious root formation is important for the acclimatization stage, since whole plants would not need a higher energy expenditure with the synthesis of new roots after transplanting to the ex vitro environment. $H$. speciosa plants from indirect organogenesis rooted in vitro were successfully acclimatized exhibiting a 100\% survival (Figure 6).

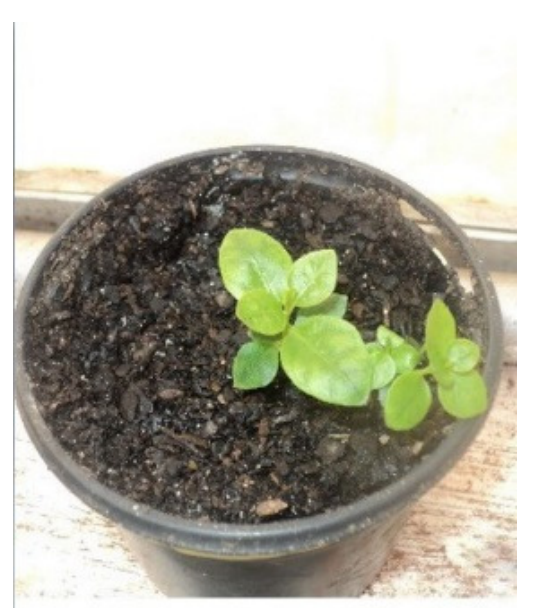

Figure 6. Developmental aspects of $H$. speciosa plants acclimatized in Tropstrato ${ }^{\circledR}$ during 30 days at greenhouse.

\section{CONCLUSIONS}

The WPM culture medium supplied with $7.38 \mu \mathrm{M}$ 2,4-D provides increased callus formation with subsequent shooting regeneration in internodal stem segments of $H$. speciosa via indirect organogenesis.

The in vitro rooting of $H$. speciosa can be reached in WPM medium supplied with the combination of $4.92 \mu \mathrm{M}$ NAA and $4.92 \mu \mathrm{M}$ IBA. 
H. speciosa plants from indirect organogenesis rooted in vitro can be successfully acclimatized exhibiting $100 \%$ survival.

\section{ACKNOWLEDGEMENTS}

The authors are thankful to the Conselho Nacional de Desenvolvimento Científico e
Tecnológico (CNPq), to the Fundação de Amparo a Pesquisa do Estado de Minas Gerais (FAPEMIG), and to the Coordenação de Aperfeiçoamento de Pessoal de Nível Superior (CAPES) for the financial support provided to perform the research.

RESUMO: Hancornia speciosa Gomes é uma frutífera pertencente à família Apocynaceae e possui grande potencial social, cultural e econômico, principalmente devido à utilização de seus frutos na composição de diversos produtos do setor alimentício e para consumo in natura. Vários aspectos de sua propagação necessitam de maiores estudos, uma vez que a espécie passa por um contínuo processo de domesticação. Objetivou-se obter um protocolo de organogênese indireta e de enraizamento in vitro, com posterior aclimatização das plantas de $H$. speciosa. Para a obtenção de organogênese indireta, segmentos internodais foram inoculados em meio de cultivo WPM gelificado com ágar $7 \mathrm{~g} \mathrm{~L}^{-1}$, acrescido de $30 \mathrm{~g} \mathrm{~L}^{-1}$ de sacarose, $0,4 \mathrm{~g} \mathrm{~L}^{-1}$ de PVP e suplementado com diferentes concentrações de 2,4-D (0,0; 2,46; $7,38 ; 12,30$ e $17,22 \mu \mathrm{M})$, BAP $(0,0 ; 4,92 ; 9,84 ; 14,76$ e $19,68 \mu \mathrm{M})$ e TDZ $(0,0 ; 4,92 ; 9,84 ; 14,76$ e $19,68 \mu \mathrm{M})$. Para o enraizamento in vitro, foram utilizadas brotações com aproximadamente $6,0 \mathrm{~cm}$ de comprimento, mantidas por 15 dias em meio WPM isento de fitorreguladores e, em seguida, submetidas a tratamentos com diferentes auxinas $($ Controle; $9,84 \mu \mathrm{M}$ de AIB; 9,84 $\mu \mathrm{M}$ de ANA e 9,84 $\mu \mathrm{M}$ de AIA), bem como as combinações entre estes reguladores $(4,92 \mu \mathrm{M}$ AIA + 4,92 $\mu \mathrm{M}$ AIB; 4,92 $\mu \mathrm{M}$ ANA + 4,92 $\mu \mathrm{M}$ AIB; 4,92 $\mu \mathrm{M}$ ANA + 4,92 $\mu \mathrm{M}$ AIA). Foi observada formação de calos em todos os explantes submetidos às concentrações dos reguladores testados. A maior regeneração de brotação ocorreu com 7,38 $\mu \mathrm{M}$ de 2,4-D (73\%). Maior porcentagem de enraizamento das brotações (80\%) e raízes com maior comprimento (1,3 cm) foi verificada em meio de cultivo contendo a combinação de 4,92 $\mu \mathrm{M}$ de ANA e 4,92 $\mu \mathrm{M}$ de AIB. É possível a regeneração in vitro de $H$. speciosa. A aclimatização foi realizada com sucesso, com $100 \%$ de sobrevivência das plantas.

PALAVRAS-CHAVE: Espécie frutífera. Apocynaceae. Cerrado.

\section{REFERENCES}

BARROS, D. I.; BRUNO, R. L. A.; NUNES, H. V.; SILVA, G. C.; PEREIRA, W. E.; MENDONÇA, R. M. N. Método de extração de sementes de mangaba visando à qualidade fisiológica. Revista Brasileira de

Fruticultura, Jaboticabal, v. 28, n. 1, p. 25-27, abr. 2006.

BASKARAN, P.; VELAYUTHAM, P.; JAYABALAN, N. In vitro regeneration of Melothria maderaspatana via indirect organogenesis. In Vitro Cellular \& Developmental Biology -Plant, New York, v. 45, n. 4, p. 407 413, out. 2009. http://dx.doi.org/10.1007/s11627-008-9172-8

BONA, C. M.; SANTOS, G. D.; BIASI, L. A. Calogênese, curva de crescimento de calos e formação de suspensões celulares de Lavandula. Brazilian Journal of Agricultural Science, Recife, v. 7, n. 1, p. 17-23, 2012. http://dx.doi.org/10.5039/agraria.v7i1a1121

CHERUVATHUR, M. K.; ABRAHAM, J.; THOMAS, T. D. Plant regeneration through callus organogenesis and true-to-type conformity of plants by RAPD analysis in Desmodium gangeticum (Linn.) DC. Applied Biochemistry and Biotechnology, v. 169, n. 6, p. 1799-1810, mar. 2013. http://dx.doi.org/10.1007/s12010013-0117-2

FACHINELlO, J. C.; HOFFMANN, A.; NACHTIGAL, J. C.; KERSTEN, E.; FORTES, G. R. L. de. Propagação de plantas frutíferas de clima temperado. 2.ed. Pelotas: UFPel, 1995. 179p.

FERMINO JUNIOR, P. C. P.; PEREIRA, J. E. S. Germinação e propagação in vitro de cerejeira (Amburana acreana (Ducke) AC Smith-Fabaceae). Ciência Florestal, Santa Maria, v. 22, n. 1, p. 1-9, jan./mar. 2012. 
FORD, Y.Y.; BONHAM, E. C.; CAMERON, R. W. F.; BLAKE, P. S.; JUDD, H. L.; HARRISON-MURRAY, R. S. Adventitious rooting: examining the role of auxin in easy and a difficult-to-root plant. Plant Growth Regulation, Dordrecht, v.36, n.2, p.149-159, maio, 2001. http://dx.doi.org/10.1023/A:1015013025513

FERREIRA, D. F. A computer statistical analysis system. Ciencia e Agrotecnologia, Lavras, v. 35, n. 6, p. 1039-1042, nov./dez. 2011.

JARDIM, L. S.; SAMPAIO, P. T. B.; COSTA, S. S.; GONÇALVES, C. Q. B.; BRANDÃO, H. L. M. Effect of differents growth regulators in vitro propagation of Aniba rosaeodora Ducke. Acta Amazônica, Manaus, v. 40, n. 2, p. 275-279, jun. 2010. http://dx.doi.org/10.1590/S0044-59672010000200005

KIELSE, P.; FRANCO, E. T. H.; PARANHOS, J. T.; LIMA, A. P. S. In vitro regeneration of Parapiptadenia rigida. Ciência Rural, Santa Maria, v. 39, n. 4, p. 1088-1094, jul. 2009. http://dx.doi.org/10.1590/S010384782009005000046

LI, F.; CUI, X.; FENG, Z.; DU, X.; ZHU, J. The effect of 2,4-D and kinetin on dedifferentiation of petiole cells in Arabidopsis thaliana. Biologia Plantarum, v. 56, n.1, p. 121-125, mar. 2012.

http://dx.doi.org/10.1007/s10535-012-0026-1

LLOYD, G.; MCCOWN, B. Use of microculture for production and improvement of Rhododendro spp. HortScience, Alexandria, v. 15, n. 3, p. 416, 1980.

LORENZI, H. Árvores brasileiras: manual de identificação e cultivo de plantas arbóreas do Brasil. Nova Odessa: Plantanarum, 2000. 352p.

MACHADO, L. L.; RAMOS, M. L. G.; CALDAS, L. S.; VIVALDI, L. J. Seleção de matrizes e clones de mangabeira para o cultivo in vitro. Pesquisa Agropecuária Brasileira, Brasília, v. 39, n. 5, p. 431-435, maio 2004. http://dx.doi.org/10.1590/S0100-204X2004000500004

MANTOVANI, N. C.; GRANDO, M. F.; XAVIER, A.; OTONI, W. C. Resgate vegetativo por alporquia de genótipos adultos de urucum (Bixa orellana L.). Ciência Florestal, Santa Maria, v. 20, n. 3, p. 403-410, jul./set. 2010.

MOURA, M. D. B.; AGRA, M. F. Apocynaceaes tóxicas e medicinais ocorrentes nos estados de Pernambuco e Paraíba, Brasil. Acta Botânica Brasílica, Feira de Santana, v. 3, n. 2, p. 273-279, 1989.

http://dx.doi.org/10.1590/S0102-33061989000300022

OLIVEIRA, L. M. Q.; VALIO, I. F. M. Effects of moisture contention germination of seeds of Hancornia speciosa Gomes (Apocynaceae). Annals of Botany, Oxford, v. 69, n. 6, p. 1-5, 1992.

OLIVEIRA, L. S.; DIAS, P. C.; BRONDANI, G. E. Micropropagação de espécies florestais brasileiras. Pesquisa Florestal Brasileira, Colombo, v. 33, n. 76, p. 439-453, out./dez. 2013. http://dx.doi.org/10.4336/2013.pfb.33.76.481

PEREIRA, R. P. W.; MONTEIRO, M. B. O.; ABREU, H. S. Callogenesis in stem explants of Eucalyptus grandis (Hill ex Maiden) showing resilience in oxide calluses. Floresta e Ambiente, Seropédica, v. 20, n. 3, p. 407-416, ago. 2013.

PINTO, D. L. P.; BARROS, B. A.; VICCINI, L. F.; CAMPOS, J. M. S.; SILA, M. L.; OTONI, W. C. Ploidy stability of somatic embryogenesis-derived Passiflora cincinnata Mast. plants as assessed by flow cytometry. Plant Cell, Tissue and Organ Culture, Dordrecht, v. 103, n. 1, p. 71-79, out. 2010. http://dx.doi.org/10.1007/s11240-010-9756-y 
RAGHAVAN, V. Role of 2,4-dichlorophenoxyacetic acid (2,4-D) in somatic embryogenesis on cultured zygotic embryos of Arabidopsis: cell expansion, cell cycling, and morphogenesis during continuous exposure of embryos to 2,4-D. American Journal of Botany, Saint Louis, v. 91, n. 11, p. 1743-1756, jul. 2004. http://dx.doi.org/10.3732/ajb.91.11.1743

SANTANA NETA, L. G.; MIRANDA, M. P. S.; NEGREIROS, C. V. B.; SILVA, I. R. C. Tecnologias patenteadas para produção de frutas tropicais desidratadas. GEINTEC-Gestão, Inovação e Tecnologias, São Cristóvão, v. 3, n. 5, p. 348-361, 2013.

SANTOS, P. C. G.; ALVES, E. U.; GUEDES, R. S.; SILVA, K. B.; CARDOSO, E. A.; LIMA, C. R. Qualidade de sementes de Hancornia speciosa Gomes em função do tempo de secagem. Semina: Ciências Agrárias, Londrina, v. 31, n. 2, p. 343-352, abr./jun. 2010. http://dx.doi.org/10.5433/1679-

0359.2010v31n2p343

SANTOS FILHO, E. M.; MIRANDA, M. V. C.; OLIVEIRA, C. J.; MESQUITA, F. O.; MEDEIROS, J. S.; SANTOS, W. O. Caracterização da distribuição e algumas perdas de pós-colheita do maracujá amarelo produzido no município de Cuité-pb. Agropecuária Científica no Semiárido, Campina Grande, v. 10, n. 1, jan./mar. 2014.

SILVA JÚNIOR, J. F. A cultura da mangaba. Revista Brasileira de Fruticultura, Jaboticabal, v. 26, n. 1, p. 1, 2004.

SOARES, F. P.; PAIVA, R.; ALVARENGA, A. A.; NERY, F. C.; VARGAS, D. P.; SILVA, D. R. G. Taxa de multiplicação e efeito residual de diferentes fontes de citocinina no cultivo in vitro de Hancornia speciosa Gomes. Ciência e Agrotecnologia, Lavras, v. 35, n. 1, p. 152-157, jan./fev. 2011

SOUSA, C. S.; SILVA, S. A.; COSTA, M. A. P. C.; DANTAS, A. C. V. L.; FOnSECA, A. A.; COSTA, C. A. L. C.; ALMEIDA, W. A. B. PEIXOTO, C. P. Mangaba: perspectivas e potencialidades. Bahia Agrícola, Salvador, v. 7, n. 1, p. 29-31, 2005.

SOUZA, A. V.; BERTONI, B. W.; FRANÇA, S. C.; PEREIRA, A. M. S. Micropropagation of Dioscorea multiflora Grised. Ciência e Agrotecnologia, Lavras, v. 35, n. 1, p. 92-98, jan./fev. 2011.

ULISSES, C.; WILlADINO, L.; ALBUQUERQUE, C. C.; CÂMARA, T. R. Clonagem vegetal. Anais da Academia Pernambucana de Ciência Agronômica, Recife, v. 7, p. 86-91, 2010.

VASCONCELOS, J. N. C.; CARDOSO, N. S. N.; OLIVEIRA, L. M.; SANTANA, J. R. F.; FERNANDEZ, L. G.; BELO KOBLITZ, M. G.; SILVA, M. L. C. Indução, caracterização bioquímica e ultra-estrutural de calos de aroeira-do-sertão (Myracrodruon urundeuva Fr. All.). Revista Brasileira Plantas Medicinais, Botucatu, v. 14, n. 4, p. 592-7, 2012. 